\title{
PERBANDINGAN HASIL PERAMALAN JUMLAH WISATAWAN MANCANEGARA DENGAN METODE BOX-JENKINS DAN EXPONENTIAL SMOOTHING
}

\author{
Emma Novita Sari $1^{1}$, Bambang Susanto $2^{2}$, Adi Setiawan $3^{3}$ \\ 1,2,3 Program Studi Matematika, Fakultas Sains dan Matematika, Universitas Kristen Satya Wacana.
}

e-mail: $\underline{662017012 @ \text { @student.uksw.edu }}$

\begin{abstract}
Abstrak
Peramalan jumlah kunjungan wisatawan dibutuhkan oleh pelaku usaha pariwisata untuk memberikan gambaran jumlah wisatawan di masa yang akan datang sehingga permasalahan yang mungkin terjadi dapat teratasi dengan baik. Penelitian ini bertujuan untuk membandingkan hasil peramalan jumlah wisman dengan menggunakan metode Box-Jenkins dan Exponential Smoothing. Data yang digunakan ada dua yaitu data jumlah wisatawan mancanegara yang berkunjung ke Indonesia periode Januari 2008 hingga Desember 2017 (Data I) dan Bali menurut pintu masuk Bandara Ngurah Rai Januari 2009 hingga Maret 2020 (Data II). Hasil peramalan terbaik diperoleh dengan membandingkan nilai Root of Mean Square Error (RMSE). Perbandingan hasil peramalan pada Data I menunjukkan bahwa metode Holt-Winters Exponential Smoothing lebih tepat untuk memprediksi jumlah wisman yang berkunjung ke Indonesia karena memiliki nilai RMSE yang lebih kecil. Sedangkan hasil peramalan periode 2 dan 3 pada Data II menunjukkan hasil yang jauh berbeda dengan data aslinya. Setelah dilakukan pelacakan, ternyata hal tersebut disebabkan oleh faktor tak terduga yaitu pandemi Covid-19 yang menyebabkan jumlah wisatawan turun secara signifikan selama periode tersebut.

Kata Kunci: Box-Jenkins, Exponential Smoothing, Forecasting, Foreign Tourists, Time Series
\end{abstract}

\begin{tabular}{l}
\hline \hline Abstract \\
Forecasting the number of tourist visits is needed by tourism businesses to provide an overview \\
of the number of tourists in the future so that problems that might occur can be overcome \\
properly. This study aims to compare the results of forecasting the number of foreign tourists \\
using the Box-Jenkins and Exponential Smoothing methods. There are two data used, namely \\
data on the number of foreign visitors visiting Indonesia from January 2008 to December 2017 \\
(Data I) and Bali according to the entrance of Ngurah Rai Airport from January 2009 to March \\
2020 (Data II). The best forecast results are obtained by comparing the Root of Mean Square \\
Error (RMSE) values. The comparison of forecasting results in Data I shows that the Holt- \\
Winters Exponential Smoothing method is more appropriate to predict the number of foreign \\
tourists visiting Indonesia because it has a smaller RMSE value. While, the results of forecasting \\
periods 2 and 3 in Data II show results that are far different from the original data. After \\
tracking, it turns out this is caused by an unexpected factor, the Covid-19 pandemic which \\
caused the number of tourists to drop significantly during this period. \\
Keywords: Box-Jenkins, Exponential Smoothing, Forecasting, Foreign Tourists, Time Series. \\
\hline \hline
\end{tabular}




\section{PENDAHULUAN}

Sektor pariwisata memiliki peranan yang penting bagi perekonomian Indonesia (Sujai 2016). Pertambahan jumlah kunjungan wisatawan mancanegara menjadi salah satu indikator perkembangan pariwisata (Yakup 2019). Pada tahun 2019, jumlah wisatawan mancanegara di Indonesia sebesar 16,11 juta (Kompas 2020). Jumlah tersebut naik 1,88 persen jika dibandingkan dengan tahun sebelumnya (Kompas 2020). Peningkatan jumlah wisatawan yang tidak terduga dapat berdampak pada kurang maksimalnya para pelaku pariwisata dalam memberikan pelayanan sehingga menimbulkan kekecewaan bagi wisatawan (Rahmad et al. 2018). Sebaliknya, jumlah wisatawan yang turun terus-menerus dapat berdampak pada sektor perekonomian karena dikhawatirkan jumlah pengangguran akan meningkat di Indonesia (Rahmad et al. 2018). Untuk itu, perlu dilakukan suatu peramalan yang dapat memberikan gambaran mengenai jumlah wisatawan pada waktu yang akan dating. Peramalan dapat dilakukan menggunakan analisis runtun waktu. Beberapa metode yang dapat digunakan adalah metode Box-Jenkins dan Exponential Smoothing. Metode BoxJenkins memanfaatkan data masa lalu dan data saat ini untuk peramalan (Anggriningrum et al. 2013). Sedangkan metode Exponential Smoothing merupakan metode rata-rata bergerak dengan pemberian bobot terhadap data masa lalu secara eksponensial sehingga data yang lebih baru mempunyai bobot lebih besar (Nisa 2017). (Aditya 2019) menggunakan metode Box-Jenkins dalam skripsinya. Penelitian tersebut menggunakan model MA(14) untuk peramalan. Sedangkan metode Exponential Smoothing pernah digunakan oleh (Agustine and Manuharawati 2017) dengan melakukan perbandingan antara metode Single Exponential Smoothing dan Double Exponential Smoothing (Holt).

Metode Box-Jenkins banyak digunakan dalam penelitian, baik dalam buku, artikel, maupun skripsi. Sedangkan metode Exponential Smoothing terus dikembangkan, seperti adanya versi Robust Exponential Smoothing. Metode Box-Jenkins dan Exponential Smoothing dapat digunakan pada hampir semua jenis pola data, baik data yang memiliki pola horizontal, tren, maupun musiman. Penulis tertarik untuk menggunakan kedua metode tersebut dan membandingkan metode mana yang lebih tepat digunakan untuk meramalkan jumlah wisatawan mancanegara. Perbandingan dilakukan dengan melihat nilai Root Mean Squared Error (RMSE). Penelitian ini diharapkan mampu memberikan gambaran kepada para pelaku pariwisata mengenai jumlah wisatawan mancanegara sehingga permasalahanpermasalahan yang mungkin terjadi dapat diatasi dengan baik.

\section{METODE PENELITIAN}

\subsection{Data}

Penelitian ini menggunakan dua data untuk membandingkan, yaitu data bulanan jumlah wisatawan mancanegara ke Indonesia dengan periode dari Januari 2008 sampai Desember 2017 (Data I) yang diperoleh dari situs resmi BPS dan jumlah wisatawan mancanegara ke Bali melalui Bandara Ngurah Rai dengan periode dari Januari 2009 - Maret 2020 (Data II) yang diperoleh dari situs resmi BPS Provinsi Bali . Masing-masing data dibagi menjadi data in-sample (digunakan pada langkah-langkah pemodelan sehingga didapatkan model terbaik) dan out-sample (digunakan untuk memeriksa keakuratan hasil peramalan dengan model terbaik yang telah ditentukan menggunakan data in-sample).

\subsection{Analisis Data}

Analisis data menggunakan bantuan program R. Langkah-langkah yang dilakukan adalah sebagai berikut. 


\section{Plot Data}

Dengan membuat plot awal dari data runtun waktu, maka dapat dilihat apakah data tersebut mengandung unsur tren atau tidak. Selain itu, ada atau tidaknya unsur musiman juga dapat dilihat pada plot data.

\section{Analisis Metode Box-Jenkins}

Langkah-langkah yang dilakukan adalah sebagai berikut (Rosadi 2018).

a. Preprocessing data dan identifikasi model stasioner.

Metode Box-Jenkins mengharuskan data yang diolah memenuhi syarat stasioner dalam rata-rata dan varian (Hermawan 2011). Kestasioneran dapat dilihat dari plot data runtun waktu dan plot ACF ataupun dengan melakukan uji akar unit terhadap data. Apabila data tersebut mengandung unsur tren, maka data non stasioner dalam rata-rata dan plot $\mathrm{ACF} / \mathrm{PACF}$ akan menurun secara perlahan. Preprocessing data seperti transformasi Box-Cox atau differencing juga dilakukan apabila data yang digunakan belum stasioner. Setelah data stasioner, tahap selanjunya adalah menduga model dengan memperhatikan plot ACF dan PACF.

b. Estimasi parameter dari model.

Langkah selanjutnya adalah mengestimasi parameter dalam model yang telah didapatkan. Pada tahap ini, peneliti juga akan melakukan uji signifikansi parameter.

c. Uji diagnostik dan pemilihan model terbaik.

Langkah ini terdiri dari uji White Noise dan normalitas untuk residual. Uji residual White Noise dapat dilakukan dengan uji Ljung-Box dan uji residual berdistribusi normal dapat dilakukan dengan uji Kolmogorov-Smirnov (Asalia 2018). Pemilihan model terbaik dilakukan dengan memilih model yang memiliki nilai AIC terkecil (Laura 2019).

d. Peramalan dengan model terbaik.

\section{Analisis Metode Exponential Smoothing}

Packages yang digunakan pada program R untuk metode Exponential Smoothing adalah HoltWinters dan robets (Robust Exponential Smoothing). Langkahlangkah yang dilakukan adalah sebagai berikut.

a. Memilih metode yang tepat untuk data (misalnya Single Exponential Smoothing untuk data yang tidak mengandung unsur tren maupun musiman, Double Exponential Smoothing untuk data dengan unsur tren, atau yang lain).

b. Mencari nilai parameter pemulusan yang meminimumkan nilai error. Untuk mendapatkan nilai parameter yang baik dan optimum, diperlukan alat bantu program perangkat lunak.

c. Mencari nilai awal/inisialisasi (misalnya nilai awal untuk level pada Single Exponential Smoothing; nilai awal untuk level dan tren pada Double Exponential Smoothing; atau nilai awal untuk level, tren, dan musiman pada Holt-Winters Exponential Smoothing).

d. Peramalan.

\section{Perbandingan Hasil Peramalan}

Untuk melihat akurasi hasil peramalan pada data out-sample, dapat digunakan Root Mean Squared Error (RMSE). Akurasi akan semakin tinggi jika nilai RMSE semakin kecil. Rumus RMSE adalah (Insani 2015):

$$
R M S E=\sqrt{\frac{1}{n} \sum_{t=1}^{n}\left(X_{t}-\hat{X}_{t}\right)^{2}}
$$


dengan:

$X_{t}$ : data aktual pada waktu $t$,

$\hat{X}_{t}$ : nilai hasil peramalan pada waktu $t$,

$n$ : banyaknya data out-sample.

\section{HASIL DAN PEMBAHASAN}

\subsection{Peramalan Jumlah Wisatawan Mancanegara ke Indonesia}

Data dibagi menjadi data in-sample (Januari 2008 - Desember 2016) dan data outsample (Januari 2017 - Desember 2017). Plot data in-sample dan plot ACF dari data tersebut ditunjukkan pada Gambar 1. Data mengandung unsur tren dan musiman.

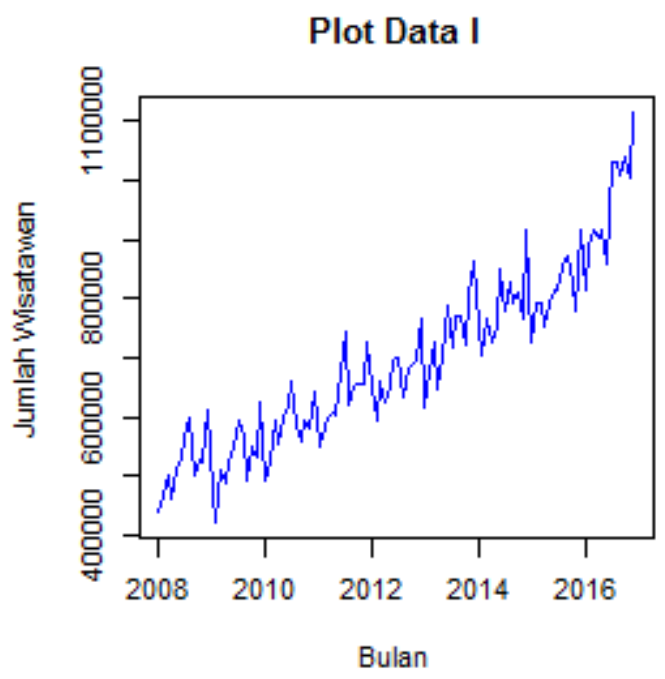

(a)
Plot ACF Data I

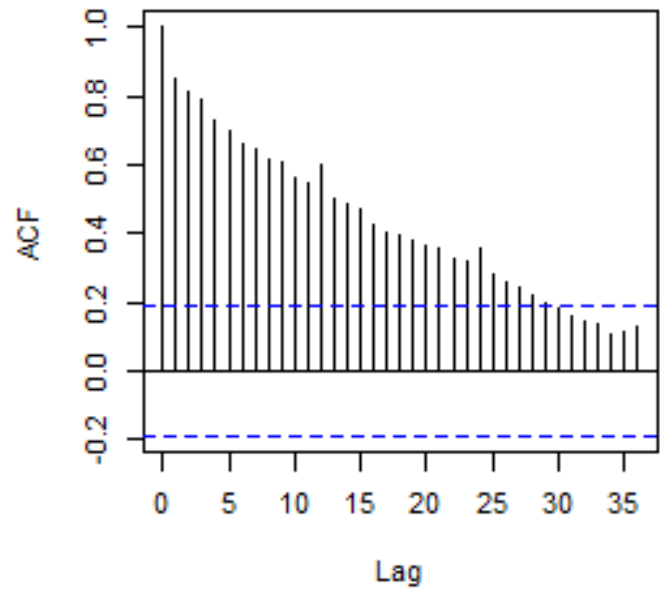

(b)

Gambar 1 (a) Plot Data I dan (b) Plot ACF Data I

\section{Analisis Metode Box-Jenkins}

Berdasarkan Gambar 1(b), terlihat bahwa data tidak stasioner karena plot ACF meluruh secara lambat menuju nol dan menunjukkan pola musiman periode 12 sehingga perlu dilakukan differencing terhadap unsur tren dan musiman. Sebelum melakukan differencing, dilakukan transformasi logaritma untuk menstabilkan variansi.

Data mengandung musiman dikarenakan terdapat pola yang sama dalam suatu periode yang tetap. Model yang digunakan adalah ARIMA musiman atau Seasonal ARIMA (SARIMA). Plot ACF dan plot PACF untuk data hasil difference logaritma musiman dan non musiman ditunjukkan pada Gambar 2. 
Plot ACF Data I Hasil Diferensiasi

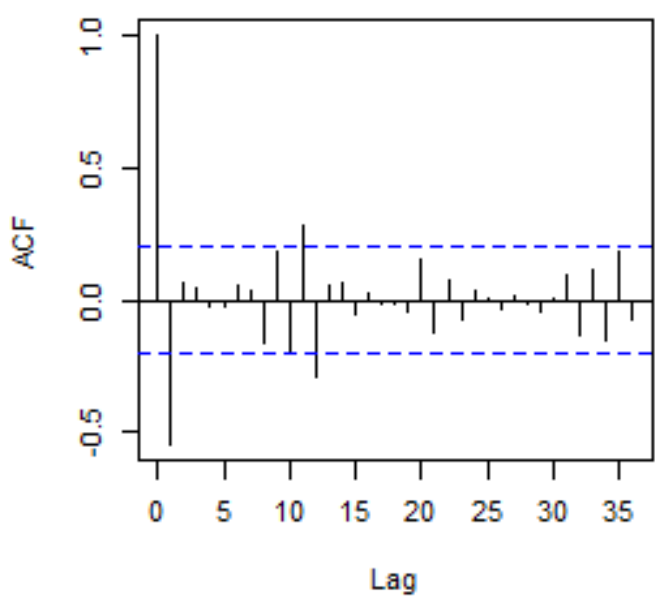

(a)
Plot PACF Data I Hasil Diferensiasi

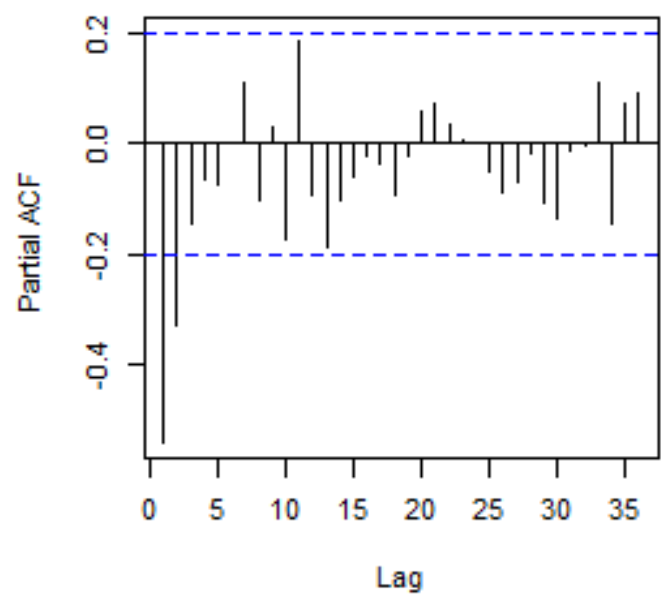

(b)

Gambar 2 Plot ACF dan Plot PACF Data I Hasil Diferensiasi

Plot ACF terpotong setelah lag-1 dan signifikan pada lag-12, sehingga diperoleh model non musiman $\operatorname{MA}(q)=1$ dan model musiman $\operatorname{MA}(Q)=1$. Plot PACF terpotong setelah lag ke2 sehingga diperoleh model non musiman $\operatorname{AR}(p)=2$ dan model musiman $\operatorname{AR}(P)=0$. Untuk $d$ non musiman dan $D$ musiman bernilai 1 karena masing-masing melalui proses differencing satu kali. Dengan kombinasi $p=2, d=1, q=1, P=0, D=1$, dan $Q=1$, dapat diperoleh kemungkinan-kemungkinan model SARIMA $(p, d, q)(P, D, Q)^{S}$ sebagai berikut.

1. $\operatorname{SARIMA}(2,1,0)(0,1,0)^{12}$

2. $\operatorname{SARIMA}(2,1,0)(0,1,1)^{12}$

3. $\operatorname{SARIMA}(0,1,1)(0,1,0)^{12}$

4. $\operatorname{SARIMA}(0,1,1)(0,1,1)^{12}$

5. $\operatorname{SARIMA}(2,1,1)(0,1,0)^{12}$

6. $\operatorname{SARIMA}(2,1,1)(0,1,1)^{12}$

Langkah selanjutnya adalah mengestimasi parameter dalam model yang telah didapatkan dan menguji apakah koefisien hasil estimasi signifikan atau tidak. Hasil estimasi parameter dan uji signifikansinya ditunjukkan pada Tabel 1. Model 1, 2, 3, dan 4 memiliki nilai sign. lebih kecil dari $\alpha=0,05$ untuk semua parameternya. Sedangkan model 5 dan 6 tidak memenuhi uji signifikansi parameter sehingga kedua model tersebut dibuang. 
Tabel 1 Hasil Estimasi dan Uji Signifikansi Data I

\begin{tabular}{|c|c|c|c|c|c|}
\hline \multirow{2}{*}{ Model } & \multicolumn{2}{|c|}{ Parameter } & \multirow{2}{*}{ SE } & \multirow{2}{*}{ sign. } & \multirow{2}{*}{ Signifikansi } \\
\hline & Tipe & Nilai & & & \\
\hline \multirow{2}{*}{1} & $\mathrm{AR}(1)$ & $-0,7592$ & 0,0976 & 0,0000 & $\checkmark$ \\
\hline & $\mathrm{AR}(2)$ & $-0,3457$ & 0,0980 & 0,0006 & $\checkmark$ \\
\hline \multirow{3}{*}{2} & $\mathrm{AR}(1)$ & $-0,7261$ & 0,0973 & 0,0000 & $\checkmark$ \\
\hline & $\mathrm{AR}(2)$ & $-0,3553$ & 0,0963 & 0,0004 & $\checkmark$ \\
\hline & SMA(1) & $-0,3968$ & 0,1375 & 0,0047 & $\checkmark$ \\
\hline 3 & $\mathrm{AR}(1)$ & $-0,5709$ & 0,0866 & 0,0000 & $\checkmark$ \\
\hline \multirow{2}{*}{4} & $\mathrm{MA}(1)$ & $-0,7183$ & 0,0735 & 0,0000 & $\checkmark$ \\
\hline & SMA(1) & $-0,5034$ & 0,1512 & 0,0012 & $\checkmark$ \\
\hline \multirow{3}{*}{5} & $\mathrm{AR}(1)$ & $-0,4184$ & 0,2516 & 0,0992 & $x$ \\
\hline & $\operatorname{AR}(2)$ & $-0,1539$ & 0,1835 & 0,4035 & $x$ \\
\hline & MA(1) & $-0,3891$ & 0,2432 & 0,1126 & $x$ \\
\hline \multirow{4}{*}{6} & $\mathrm{AR}(1)$ & $-0,2720$ & 0,2695 & 0,3151 & $x$ \\
\hline & $\operatorname{AR}(2)$ & $-0,1065$ & 0,1921 & 0,5805 & $x$ \\
\hline & MA(1) & $-0,5161$ & 0,2586 & 0,0485 & $\checkmark$ \\
\hline & SMA(1) & $-0,4436$ & 0,1526 & 0,0044 & $\checkmark$ \\
\hline
\end{tabular}

Langkah selanjutnya adalah uji diagnostik yang terdiri dari uji White Noise dan normalitas untuk residual. Uji residual White Noise dilakukan dengan uji Ljung-Box dan uji residual berdistribusi normal dilakukan dengan uji Kolmogorov-Smirnov. Tabel 2 menunjukkan hasil uji diagnostik dari model 1, 2, 3, dan 4. Model-model tersebut memenuhi kedua uji karena memiliki nilai $p$-value lebih besar dari $\alpha=0,05$. Untuk memilih model terbaik, dipilih model yang memiliki nilai AIC terkecil, yaitu $\operatorname{SARIMA}(0,1,1)(0,1,1)^{12}$.

Tabel 2 Hasil Uji Diagnostik Data I

\begin{tabular}{cccc}
\hline \multirow{2}{*}{ Model } & \multicolumn{2}{c}{$p$-value } & \multirow{2}{*}{ AIC } \\
\cline { 2 - 3 } & White Noise & Distribusi Normal & \\
\hline SARIMA $(2,1,0)(0,1,0)^{12}$ & 0,4716 & 0,2604 & $-254,25$ \\
SARIMA $(2,1,0)(0,1,1)^{12}$ & 0,8112 & 0,6757 & $-261,08$ \\
SARIMA $(0,1,1)(0,1,0)^{12}$ & 0,5669 & 0,4736 & $-254,51$ \\
SARIMA $(0,1,1)(0,1,1)^{12}$ & 0,7514 & 0,2747 & $-264,17$ \\
\hline
\end{tabular}

Hasil peramalan 12 periode yang akan datang menggunakan model $\operatorname{SARIMA}(0,1,1)(0,1,1)^{12}$ ditunjukkan pada Tabel 3.

\section{Analisis Metode Exponential Smoothing}

\section{Menggunakan Package Hol tWinters}

Karena data mengandung tren dan musiman, maka digunakan tiga parameter pemulusan. Model yang digunakan adalah model Holt-Winters aditif. Hasil yang diperoleh dari program $\mathrm{R}$ adalah sebagai berikut.

a) Nilai parameter: $\alpha=0,2977594, \beta=0,06180483$, dan $\gamma=0,5556765$.

b) Nilai pemulusan level periode $n$ :

$S_{108}=1018376,48783$.

c) Nilai pemulusan tren periode $n$ :

$b_{108}=9993,22526$.

d) Nilai pemulusan pola musiman 12 periode terakhir: 


$$
\begin{array}{ll}
I_{97}=-33086,70643, & I_{103}=60437,47037, \\
I_{98}=79,66024, & I_{104}=57756,68989, \\
I_{99}=13591,78381, & I_{105}=33315,15072, \\
I_{100}=-27361,99677, & I_{106}=25216,47226, \\
I_{101}=-10094,22653, & I_{107}=-12609,68405, \\
I_{102}=-5169,66491, & I_{108}=97581,55389 .
\end{array}
$$

Hasil peramalan untuk 12 periode yang akan datang ditunjukkan pada Tabel 3.

\section{Menggunakan Packages robets}

Model yang digunakan adalah M,A $\mathrm{d}, \mathrm{A}$ atau Exponential Smoothing dengan model dasar multiplikatif, damped additive trend, dan musiman aditif. Nilai parameter yang diperoleh adalah $\alpha=0,5181, \beta=0,0797, \gamma=0,1505$, dan $\phi=0,8656$. Kemudian, nilai awal yang diperoleh adalah sebagai berikut.

a) $\hat{\sigma}_{0}=0,0309$.

b) Pemulusan level: $l_{0}=471289,8788$.

c) Pemulusan tren: $b_{0}=3814,2121$.

d) Pemulusan musiman:

$$
\begin{array}{ll}
S_{-11}=66823,39, & S_{-5}=27705,76, \\
S_{-10}=-2461,394, & S_{-4}=-14396,48, \\
S_{-9}=-4173,182, & S_{-3}=-27417,73, \\
S_{-8}=5115,97, & S_{-2}=-7212,697, \\
S_{-7}=6814,667, & S_{-1}=-48172,94, \\
S_{-6}=68945,55, & S_{0}=-47709,64 .
\end{array}
$$

Hasil peramalan untuk 12 periode yang akan datang ditunjukkan pada Tabel 3.

\section{Perbandingan Hasil Peramalan}

Perbandingan hasil peramalan menggunakan metode SARIMA, Holt-Winters, dan Robust Exponential Smoothing ditunjukkan pada Tabel 3.

Tabel 3 Perbandingan Hasil Peramalan Data I

\begin{tabular}{ccccc}
\hline & & \multicolumn{3}{c}{ Hasil Peramalan } \\
\cline { 3 - 5 } Periode & Data Aktual & \multirow{2}{*}{ SARIMA } & Exponential Smoothing \\
\cline { 3 - 5 } & & 959.217 & 995.283 & Robust \\
\hline 1 & 1.107 .968 & 1.019 .857 & 1.038 .443 & 1.010 .679 \\
2 & 1.023 .388 & 1.056 .890 & 1.061 .948 & 1.046 .388 \\
3 & 1.059 .777 & 1.017 .974 & 1.030 .987 & 1.017 .431 \\
4 & 1.171 .386 & 1.052 .759 & 1.058 .248 & 1.048 .139 \\
5 & 1.148 .588 & 1.054 .839 & 1.073 .166 & 1.083 .888 \\
6 & 1.144 .001 & 1.140 .151 & 1.148 .767 & 1.123 .439 \\
7 & 1.370 .591 & 1.158 .708 & 1.156 .079 & 1.103 .371 \\
8 & 1.393 .243 & 1.145 .633 & 1.141 .631 & 1.079 .729 \\
9 & 1.250 .231 & 1.149 .530 & 1.143 .525 & 1.072 .962 \\
10 & 1.161 .565 & 1.111 .490 & 1.115 .692 & 1.058 .866 \\
11 & 1.062 .030 & 1.260 .819 & 1.235 .877 & 1.156 .628 \\
12 & 1.147 .031 & 128259,1 & $\mathbf{1 2 0 4 7 3 , 1}$ & 139585,9 \\
\hline
\end{tabular}


Berdasarkan Tabel 3, dapat diketahui bahwa metode Holt-Winters lebih tepat digunakan untuk peramalan karena memiliki nilai RMSE yang paling kecil.

\section{Peramalan Jumlah Wisatawan Mancanegara ke Bali}

Data dibagi menjadi data in-sample (Januari 2009 - Desember 2019) dan data outsample (Januari 2020 - Maret 2020). Plot data in-sample dan plot ACF dari data tersebut ditunjukkan pada Gambar 3. Data mengandung unsur tren dan musiman.

Plot Data II

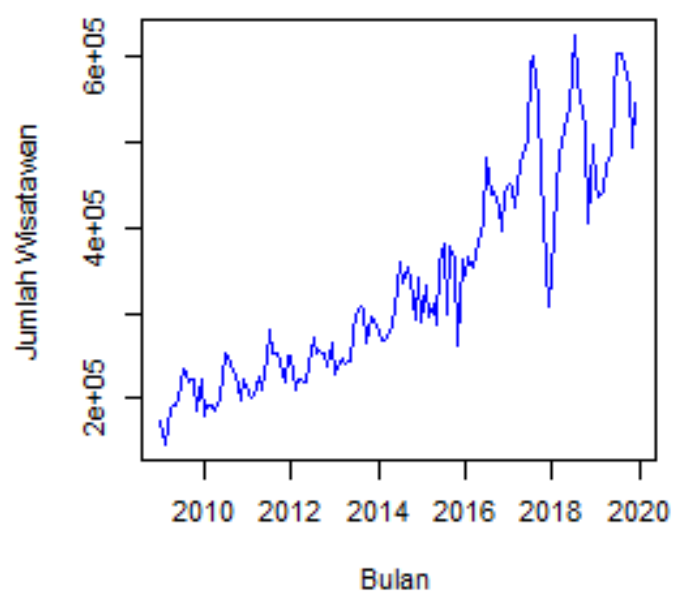

(a)
Plot ACF Data II

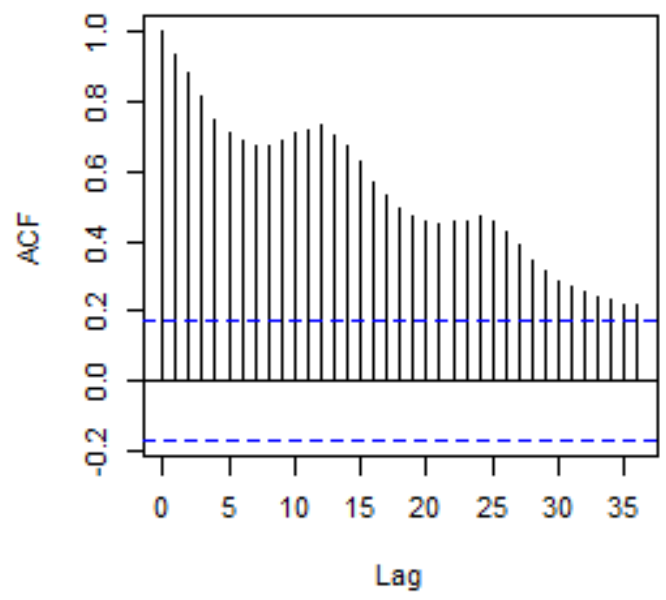

(b)

Gambar 3 (a) Plot Data II dan (b) Plot ACF Data II

\section{Analisis Metode Box-Jenkins}

Berdasarkan Gambar 3(a), terlihat bahwa data tidak stasioner karena plot ACF meluruh secara lambat menuju nol dan menunjukkan pola musiman periode 12 sehingga perlu dilakukan differencing terhadap unsur tren dan musiman. Sebelum melakukan differencing, dilakukan transformasi logaritma untuk menstabilkan variansi.

Data mengandung musiman dikarenakan terdapat pola yang sama dalam suatu periode yang tetap. Model yang digunakan adalah ARIMA musiman atau Seasonal ARIMA (SARIMA). Plot ACF dan plot PACF untuk data hasil difference logaritma musiman dan non musiman ditunjukkan pada Gambar 4. 
Plot ACF Data II Hasil Diferensiasi

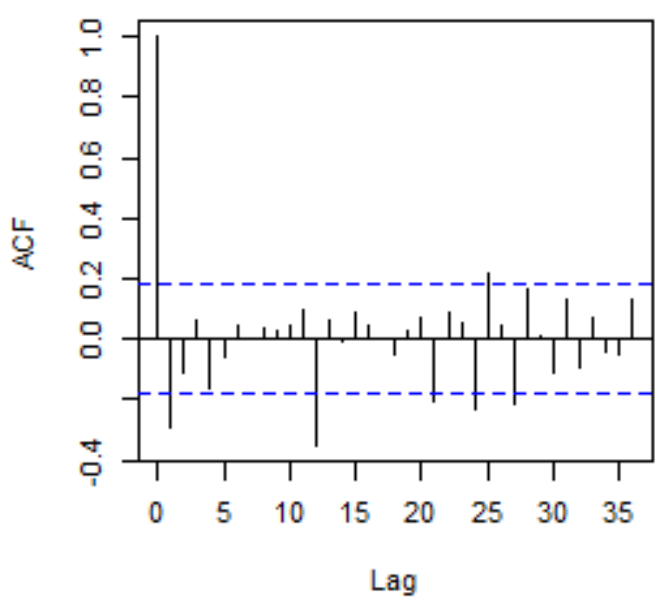

(a)
Plot PACF Data II Hasil Diferensiasi

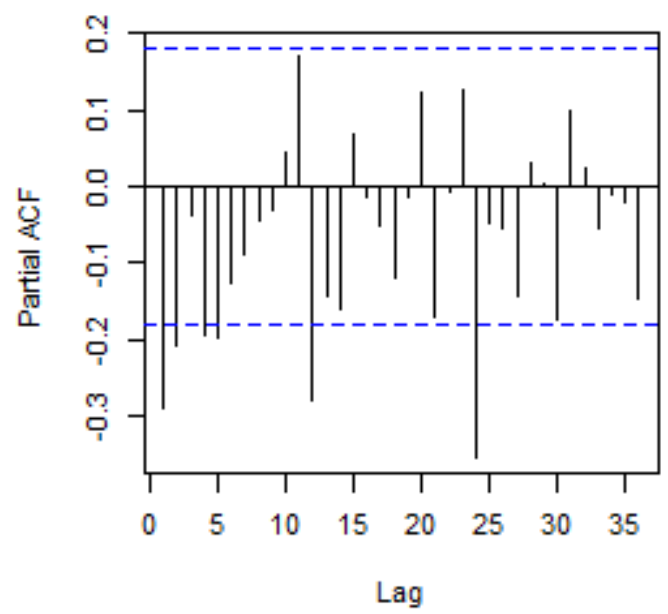

(b)

Gambar 4 Plot ACF dan PACF Data II Hasil Diferensiasi

Plot ACF terpotong terpotong setelah lag-1 dan signifikan pada lag-12 dan 24, sehingga diperoleh model non musiman $\mathrm{MA}(q)=1$ dan model musiman $\mathrm{MA}(Q)=2$. Plot PACF terpotong setelah lag ke-2 dan signifikan pada lag-12 dan 24, sehingga diperoleh model non musiman $\operatorname{AR}(p)=2$ dan model musiman $\operatorname{AR}(P)=2$. Untuk $d$ non musiman dan $D$ musiman bernilai 1 karena masing-masing melalui proses differencing satu kali. Dengan kombinasi $p=2, d=1, q=1, P=2, D=1$, dan $Q=2$, dapat diperoleh kemungkinan-kemungkinan model SARIMA $(p, d, q)(P, D, Q)^{S}$ sebagai berikut.

1. $\operatorname{SARIMA}(2,1,0)(2,1,0)^{12}$

2. $\operatorname{SARIMA}(2,1,0)(0,1,2)^{12}$

3. $\operatorname{SARIMA}(2,1,0)(2,1,2)^{12}$

4. $\operatorname{SARIMA}(0,1,1)(2,1,0)^{12}$

5. $\operatorname{SARIMA}(0,1,1)(0,1,2)^{12}$

6. $\operatorname{SARIMA}(0,1,1)(2,1,2)^{12}$

7. $\operatorname{SARIMA}(2,1,1)(0,1,0)^{12}$

8. $\operatorname{SARIMA}(2,1,1)(0,1,1)^{12}$

9. $\operatorname{SARIMA}(2,1,1)(2,1,1)^{12}$

Langkah selanjutnya adalah mengestimasi parameter dalam model yang telah didapatkan dan menguji apakah koefisien hasil estimasi signifikan atau tidak. Hasil estimasi parameter dan uji signifikansinya ditunjukkan pada Tabel 4 . Model 4 memiliki nilai sign. lebih kecil dari $\alpha=0,05$ untuk semua parameternya. Sedangkan model yang lain tidak memenuhi uji signifikansi parameter sehingga model-model tersebut dibuang.

Tabel 4 Hasil Estimasi dan Uji Signifikansi Data II

\begin{tabular}{|c|c|c|c|c|c|}
\hline \multirow{2}{*}{ Model } & \multicolumn{2}{|c|}{ Parameter } & \multirow{2}{*}{ SE } & \multirow{2}{*}{ sign. } & \multirow{2}{*}{ Signifikansi } \\
\hline & Tipe & Nilai & & & \\
\hline \multirow{4}{*}{1} & $\operatorname{AR}(1)$ & $-0,3631$ & 0,0929 & 0,0001 & $\checkmark$ \\
\hline & $\operatorname{AR}(2)$ & $-0,1675$ & 0,0926 & 0,0728 & $x$ \\
\hline & SAR(1) & $-0,6034$ & 0,0879 & 0,0000 & $\checkmark$ \\
\hline & $\operatorname{SAR}(2)$ & $-0,4413$ & 0,0900 & 0,0000 & $\checkmark$ \\
\hline
\end{tabular}




\begin{tabular}{|c|c|c|c|c|c|}
\hline \multirow{4}{*}{2} & $\mathrm{AR}(1)$ & $-0,3473$ & 0,0928 & 0,0003 & $\checkmark$ \\
\hline & $\mathrm{AR}(2)$ & $-0,1851$ & 0,0920 & 0,0463 & $\checkmark$ \\
\hline & SMA(1) & $-0,8247$ & 0,2678 & 0,0025 & $\checkmark$ \\
\hline & SMA(2) & $-0,1034$ & 0,1591 & 0,5169 & $x$ \\
\hline \multirow{6}{*}{3} & $\mathrm{AR}(1)$ & $-0,3413$ & 0,0949 & 0,0005 & $\checkmark$ \\
\hline & $\mathrm{AR}(2)$ & $-0,1571$ & 0,0945 & 0,0988 & $x$ \\
\hline & SAR(1) & $-0,8020$ & 0,2891 & 0,0063 & $\checkmark$ \\
\hline & $\operatorname{SAR}(2)$ & $-0,0879$ & 0,1808 & 0,6277 & $x$ \\
\hline & $\operatorname{SMA}(1)$ & 0,0526 & 0,3227 & 0,8708 & $x$ \\
\hline & $\operatorname{SMA}(2)$ & $-0,7056$ & 0,3485 & 0,0449 & $\checkmark$ \\
\hline \multirow{3}{*}{4} & MA(1) & $-0,4275$ & 0,1064 & 0,0001 & $\checkmark$ \\
\hline & SAR(1) & $-0,5929$ & 0,0865 & 0,0000 & $\checkmark$ \\
\hline & $\operatorname{SAR}(2)$ & $-0,4485$ & 0,0886 & 0,0000 & $\checkmark$ \\
\hline \multirow{3}{*}{5} & MA(1) & $-0,4237$ & 0,1096 & 0,0002 & $\checkmark$ \\
\hline & SMA(1) & $-0,8246$ & 0,3596 & 0,0234 & $\checkmark$ \\
\hline & SMA(2) & $-0,1200$ & 0,1728 & 0,4886 & $x$ \\
\hline \multirow{5}{*}{6} & MA(1) & $-0,4057$ & 0,1109 & 0,0004 & $\checkmark$ \\
\hline & $\operatorname{SAR}(1)$ & $-0,5929$ & 0,2638 & 0,0029 & $\checkmark$ \\
\hline & SAR(2) & $-0,0869$ & 0,1836 & 0,6368 & $x$ \\
\hline & SMA(1) & 0,0699 & 0,3092 & 0,8215 & $x$ \\
\hline & SMA(2) & $-0,7160$ & 0,3417 & 0,0381 & $\checkmark$ \\
\hline \multirow{5}{*}{7} & $\mathrm{AR}(1)$ & 0,4936 & 0,1039 & 0,000 & $\checkmark$ \\
\hline & $\mathrm{AR}(2)$ & 0,1043 & 0,1047 & 0,321 & $x$ \\
\hline & MA(1) & $-0,9655$ & 0,0635 & 0,000 & $\checkmark$ \\
\hline & $\operatorname{SAR}(1)$ & $-0,5588$ & 0,0878 & 0,000 & $\checkmark$ \\
\hline & SAR(2) & $-0,4499$ & 0,0863 & 0,000 & $\checkmark$ \\
\hline \multirow{5}{*}{8} & $\mathrm{AR}(1)$ & 0,4936 & 0,1039 & 0,0000 & $\checkmark$ \\
\hline & $\mathrm{AR}(2)$ & 0,0758 & 0,1019 & 0,4583 & $x$ \\
\hline & $\mathrm{MA}(1)$ & $-0,9515$ & 0,0601 & 0,0000 & $\checkmark$ \\
\hline & SMA(1) & $-0,8463$ & 0,2920 & 0,0044 & $\checkmark$ \\
\hline & SMA (2) & $-0,1533$ & 0,1176 & 0,1947 & $x$ \\
\hline \multirow{7}{*}{9} & $\mathrm{AR}(1)$ & 0,4862 & 0,0157 & 0,0000 & $\checkmark$ \\
\hline & $\mathrm{AR}(2)$ & 0,0754 & $\mathrm{NaN}$ & $\mathrm{NaN}$ & - \\
\hline & MA(1) & $-0,9449$ & 0,0095 & 0,0000 & $\checkmark$ \\
\hline & $\operatorname{SAR}(1)$ & $-0,7552$ & 0,0165 & 0,0000 & $\checkmark$ \\
\hline & $\operatorname{SAR}(2)$ & $-0,0613$ & $\mathrm{NaN}$ & $\mathrm{NaN}$ & - \\
\hline & SMA(1) & 0,0182 & 0,0130 & 0,1639 & $x$ \\
\hline & $\operatorname{SMA}(2)$ & $-0,7399$ & $\mathrm{NaN}$ & $\mathrm{NaN}$ & - \\
\hline
\end{tabular}

Langkah selanjutnya adalah uji diagnostik yang terdiri dari uji White Noise dan normalitas untuk residual. Uji residual White Noise dilakukan dengan uji Ljung-Box dan uji residual berdistribusi normal dilakukan dengan uji Kolmogorov-Smirnov. Tabel 5 menunjukkan hasil uji diagnostik dari model 4 atau SARIMA $(0,1,1)(2,1,0)^{12}$. Model tersebut memenuhi kedua uji karena memiliki nilai $p$-value lebih besar dari $\alpha=0,05$ sehingga model tersebut layak digunakan untuk peramalan. 
Tabel 5 Hasil Uji Diagnostik Data II

\begin{tabular}{cc}
\hline \multicolumn{2}{c}{$p$-value } \\
\hline White Noise & Distribusi Normal \\
\hline 0,274 & 0,07076 \\
\hline
\end{tabular}

Hasil peramalan 3 periode yang akan datang menggunakan model $\operatorname{SARIMA}(0,1,1)(2,1,0)^{12}$ ditunjukkan pada Tabel 6.

\section{Analisis Metode Exponential Smoothing}

\section{Menggunakan Package Hol twinters}

Karena data mengandung tren dan musiman, maka digunakan tiga parameter pemulusan. Model yang digunakan adalah model Holt-Winters aditif. Hasil yang diperoleh dari program $\mathrm{R}$ adalah sebagai berikut.

a) Nilai parameter: $\alpha=0,8431165, \beta=0$, dan $\gamma=0,6031289$.

b) Nilai pemulusan level periode $n$ :

$S_{132}=533404,8547$.

c) Nilai pemulusan tren periode $n$ :

$b_{132}=1193,4385$.

d) Nilai pemulusan pola musiman 12 periode terakhir:

$$
\begin{array}{ll}
I_{121}=-12419,3926, & I_{127}=54385,6915, \\
I_{122}=-9299,0223, & I_{128}=23939,3874, \\
I_{123}=-17668,0108, & I_{129}=19204,5919, \\
I_{124}=-10655,7210, & I_{130}=314,7134, \\
I_{125}=-13090,7124, & I_{131}=-40753,2779, \\
I_{126}=15936,9729, & I_{132}=11598,8369 .
\end{array}
$$

Hasil peramalan untuk 3 periode yang akan datang ditunjukkan pada Tabel 6.

\section{Menggunakan Package robets}

Model yang digunakan adalah $\mathrm{A}, \mathrm{A}_{\mathrm{d}}, \mathrm{A}$ atau Exponential Smoothing dengan model dasar aditif, damped additive trend, dan musiman aditif. Nilai parameter yang diperoleh adalah $\alpha=0,5343, \beta=0,003, \gamma=0,0466$, dan $\phi=0,9751$. Kemudian, nilai awal yang diperoleh adalah sebagai berikut.

a) $\hat{\sigma}_{0}=8260,479$.

b) Pemulusan level:

$l_{0}=183983,454$.

c) Pemulusan tren:

$b_{0}=1517,3226$.

d) Pemulusan musiman:

$$
\begin{array}{ll}
S_{-11}=9728,933, & S_{-5}=9533,126, \\
S_{-10}=16748,74, & S_{-4}=-19153,81, \\
S_{-9}=39021,42, & S_{-3}=-22019,03, \\
S_{-8}=18799,9, & S_{-2}=-20209,03, \\
S_{-7}=28657,09, & S_{-1}=-22878,58, \\
S_{-6}=39021,42, & S_{0}=-13579,52 .
\end{array}
$$

Hasil peramalan untuk 3 periode yang akan datang ditunjukkan pada Tabel 6 . 


\section{Perbandingan Hasil Peramalan}

Perbandingan hasil peramalan menggunakan metode SARIMA, Holt-Winters, dan Robust Exponential Smoothing ditunjukkan pada Tabel 6.

Tabel 6 Perbandingan Hasil Peramalan Data II

\begin{tabular}{ccccc}
\hline \multirow{2}{*}{ Periode } & Data Aktual & \multirow{3}{*}{ Hasil Peramalan } \\
\cline { 3 - 5 } & & \multirow{2}{*}{ SARIMA } & Exponential Smoothing \\
\cline { 3 - 5 } & & 537.828 & 522.179 & 528.203 \\
2 & 528.883 & 547.180 & 526.493 & 526.410 \\
3 & 363.937 & 542.842 & 519.317 & 524.685 \\
\hline \multicolumn{2}{c}{ RMSE } & 246675,9 & 229515,5 & 232149,9 \\
\hline
\end{tabular}

Hasil peramalan periode 2 dan 3 dengan ketiga metode menunjukkan hasil yang jauh berbeda dibandingkan dengan data aslinya. Setelah ditelusur, ternyata hal itu disebabkan oleh adanya faktor lain yang tidak terduga yaitu pandemi Covid-19 yang membuat jumlah wisatawan turun secara signifikan pada periode tersebut.

\section{KESIMPULAN}

Penelitian ini membandingkan hasil peramalan dengan metode Box-Jenkins dan Exponential Smoothing (Holt-Winters dan Robust Exponential Smoothing). Data yang diolah adalah data bulanan jumlah wisatawan mancanegara di Indonesia (Januari 2008 - Desember 2017) dan jumlah wisatawan mancanegara ke Bali melalui Bandara Ngurah Rai (Januari 2009 - Maret 2020). Peramalan dengan ketiga metode untuk Data I menghasilkan nilai RMSE berturut-turut sebesar 128259,1, 120473,1, dan 139585,9. Dengan demikian, metode Holt-Winters lebih tepat digunakan untuk peramalan karena memiliki nilai RMSE yang paling kecil. Sedangkan untuk Data II, hasil peramalan periode 2 dan 3 menunjukkan hasil yang jauh berbeda dibandingkan dengan data aslinya. Setelah ditelusur, ternyata hal itu disebabkan oleh adanya faktor lain yang tidak terduga yaitu pandemi Covid-19 yang membuat jumlah wisatawan turun secara signifikan pada periode tersebut.

\section{DAFTAR PUSTAKA}

Aditya, C. C. (2019), "Peramalan Curah Hujan Di Pos Hujan Ledok Nongko Kecamatan Turi, Daerah Istimewa Yogyakarta Dengan Metode Autorgressive Integrated Moving Average (ARIMA) Box-Jenkins Menggunakan Software Eviews 10," Skripsi Yogyakarta:, Universitas Sanatha Dharma.

Agustine, A., and Manuharawati (2017), "Forecasting Fitness Gym Membership pada Pusat Kebugaran 'The Body Art Fitness, Aerobic \& Pool' menggunakan Metode Exponential Smoothing," Jurnal Ilmiah Matematika, 3, 1-7.

Anggriningrum, D. P., Hendikawati, P., and Abidin, Z. (2013), "Perbandingan Prediksi Harga Saham dengan menggunakan Jaringan Syaraf Tiruan Backpropagation dan Arima," Unnes Journal of Mathematics, 2, 104-109.

Asalia, R. (2018), "Peramalan Produksi Roti Gulung Pada Industri Rumah Tangga Lautan Kue menggunakan Metode ARIMA Berbantu Minitab 14 For Windows," Universitas Sanata Dharma.

Hermawan, E. (2011), "Perbandingan Metode Box-Jenkins dan Holt-Winters dalam Prediksi Anomali OLR Pentad di Kawasan Barat Indonesia," Jurnal Sains Dirgantara, 9, 25-35. 
Insani, N. H. (2015), "Peramalan Curah Hujan dengan menggunakan Metode ARIMA Box-Jenkins sebagai Pendukung Kalender Tanam Padi di Kabupaten Bojonegoro," Institut Teknologi Sepuluh Nopember.

Kompas (2020), “Jumlah Kunjungan Wisman ke Indonesia Pada 2019 Naik 1,88 Persen," Available at https://travel.kompas.com/read/2020/02/05/180300227/jumlahkunjungan-wisman-ke-indonesia-pada-2019-naik-1-88-persen.

Laura, V. (2019), "Peramalan Banyaknya Penabung di Credit Union Sumber Kasih Teraju dengan Metode Box-Jenkins," Universitas Sanata Dharma.

Nisa, F. A. C. (2017), "Pembandingan Metode Penghalusan Eksponensial Holt-Winters menggunakan Model Aditif dan Multiplikatif pada Peramalan Data Deret Waktu Musiman," Universitas Lampung.

Rahmad, C., Ramadhani, M. F., and Puspitasari, D. (2018), "Peramalan Jumlah Kedatangan Wisatawan Mancanegara dengan Menggunakan Metode Time Invariant Fuzzy Time Series (Studi Kasus : Wisata Kabupaten Pasuruan)," Jurnal Informatika Polinema, 4, 195-200. https://doi.org/10.33795/jip.v4i3.206.

Rosadi, D. (2018), Analisis Runtun Waktu dan Aplikasinya dengan R, Gadjah Mada University Press.

Yakup, A. P. (2019), "Pengaruh Sektor Pariwisata terhadap Pertumbuhan Ekonomi di Indonesia," Universitas Airlangga. 